\title{
First Summer Course in Animal Law in Scandinavia hosted by Aarhus University - July 2018
}

\author{
Sacha Lucassen \\ MA Animal Law and Society (UAB) \\ Lecturer, University of Aarhus
}

Received: September 2018

Accepted: October 2018

Recommended citation. LUCASSEN S., First Summer Course in Animal Law in Scandinavia hosted by Aarhus University - July 2018, dA. Derecho Animal (Forum of Animal Law Studies) 9/4 (2018) - https://doi.org/10.5565/rev/da.375

\begin{abstract}
Last July the first summer course in Animal Law took place at Aarhus University, Scandinavia, one of Europe's most renowned universities. The course was created and lectured by Sacha Lucassen (MA Animal Law and Society, UAB - 5th Edition) and welcomed students not only from all over Europe, but even from Vietnam, Kenya, China and Australia. It revolved around the main question "How and to what extend are - or should - animals be protected by the law?" Experts in different domains within the scope of Animal Law delivered valuable contributions to the course during several guest lecturers. The course put Animal Law on the academic program in Denmark and will take place again next summer.
\end{abstract}

Keywords: Scandinavia, animal law, summer course, academia.

Resumen - Primer curso de verano sobre Derecho Animal en Escandinavia en la Universidad de Aarhus - Julio 2018

El pasado mes de julio tuvo lugar el primer curso de verano sobre Derecho Animal en Escandinavia en la Universidad de Aarhus, una de las universidades más famosas de Europa. El curso fue creado y realizado por Sacha Lucassen (Máster en Derecho Animal y Sociedad, UAB - $5^{\text {a }}$ edición) y recibió a estudiantes no solo de toda Europa, sino también de Vietnam, Kenia, China y Australia. Se centró en la pregunta principal "¿Cómo y en qué medida están, o deberían estar, los animales protegidos por la ley?" Expertos en diferentes dominios dentro del ámbito del Derecho Animal proporcionaron valiosas contribuciones al curso a lo largo de varias conferencias por parte de los invitados. El curso incluyó el Derecho Animal en el programa académico en Dinamarca y se llevará a cabo de nuevo el próximo verano.

Palabras clave: Escandinavia, derecho animal, curso de verano, academia 
From the 3rd until the 20th of July 2018, Aarhus University was the setting for the first Summer Course in Animal Law in Scandinavia. It was the first time that Animal Law was part of the academic program at a law faculty in Denmark. The intensive course took place over three-weeks with classroom teaching consisting of lectures, presentations and discussions as well as a fieldtrip to see research on the welfare of animals.

The Summer Course in Animal Law welcomed students not only from all over Europe, but even from Vietnam, Kenya, China and Australia. Among the students present, there were law students, veterinarians, Ph.D. students and consultants from Ministries. A diverse class representing different cultures and traditions, proved to be an ideal setting to exchange ideas and engage in insightful discussions.

This course focused on some of the fundamental elements of the protection of animals in the legal system, while regularly making the link with morality and science, as these three disciplines intersect and continuously influence each other. New scientific findings on the state of animals lead to moral discussions on the treatment of animals, which in turn trigger new legislation in the area. As such, the course revolved around the main question" How and to what extend are - or should - animals be protected by the law?".

The emphasis of the course was on the legal protection of animals in the European Union, by exploring the path of developing primary and secondary legislation on animals within the EU institutions. At the same time, the different interests and challenges at stake when drafting regulation on animal welfare was discussed. During the final week, a special focus was given to the on-going work of the legal animal rights movement, which seeks to change the legal status of animals and provide them with fundamental rights.

Throughout the course, we covered a range of topics from studying legislation and analysing case law from national courts and the European Court of Justice, to discussing and questioning the place of animals in the legal system and what kind of legal protection they should be granted.

Experts in different domains within the scope of Animal Law made valuable contributions during several guest lectures. Professor Iyan Offor came to Aarhus to teach the important topic of trade and animal welfare. David Rosengard of the Animal Legal Defense Fund in the United States gave an introduction to the legal protection of animals in the U.S. And lecturers Tarah Daly and Alessia Bacigalupo respectively addressed the contemporary standpoints on the moral status of animals and the link between animal abuse and human violence.

Animal Law is an emerging field and I am hopeful that the first Summer Course in Animal Law in Scandinavia will serve as a seed for the continuous growth of animal law, as I believe education is the most important tool in the mission for a better world for animals. 


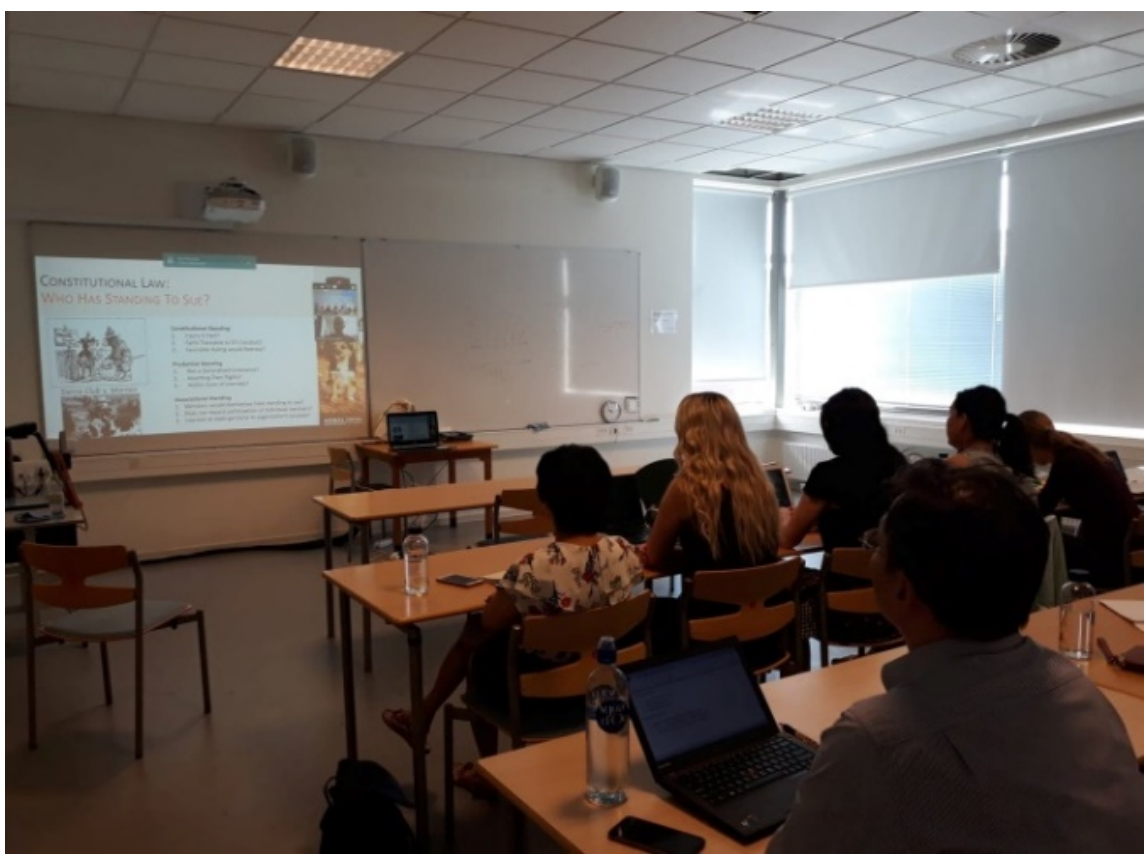

Photo - Courtesy of Sacha Lucassen

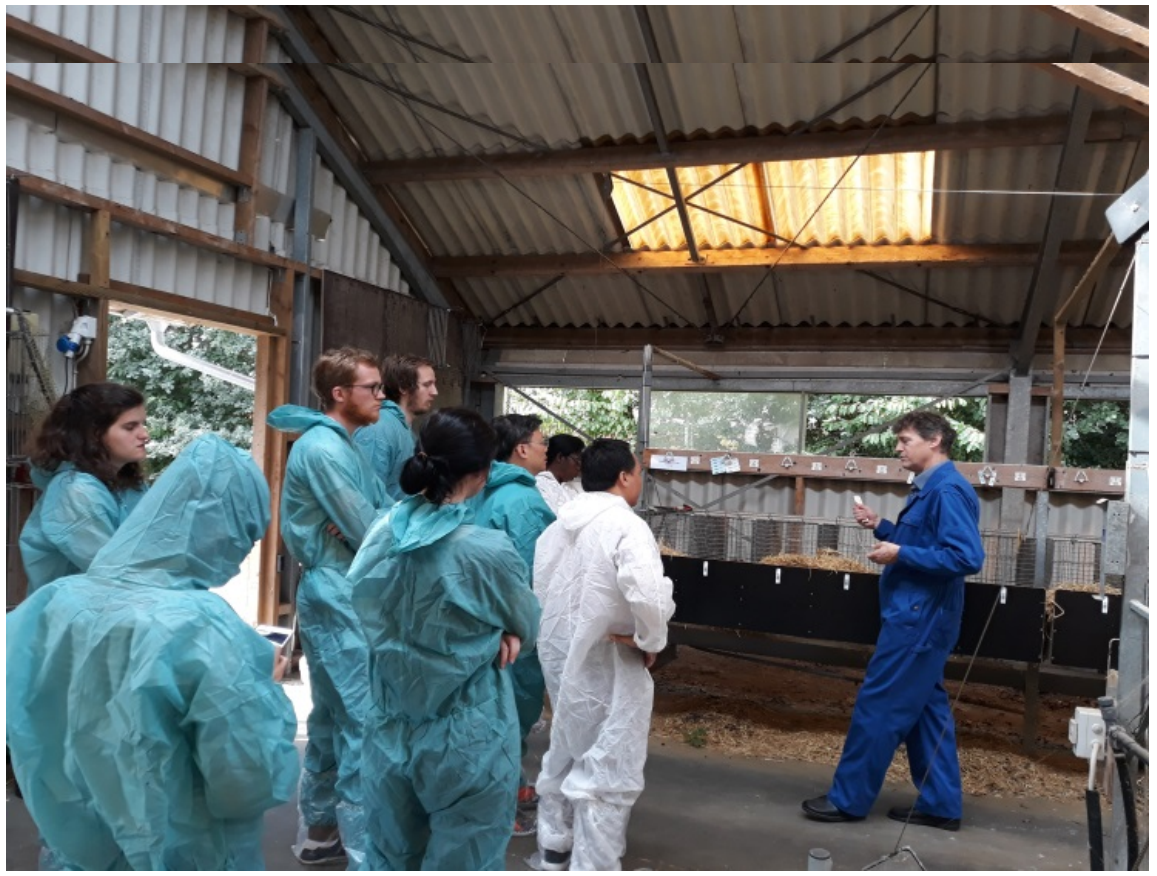

Photo - Courtesy of Sacha Lucassen 


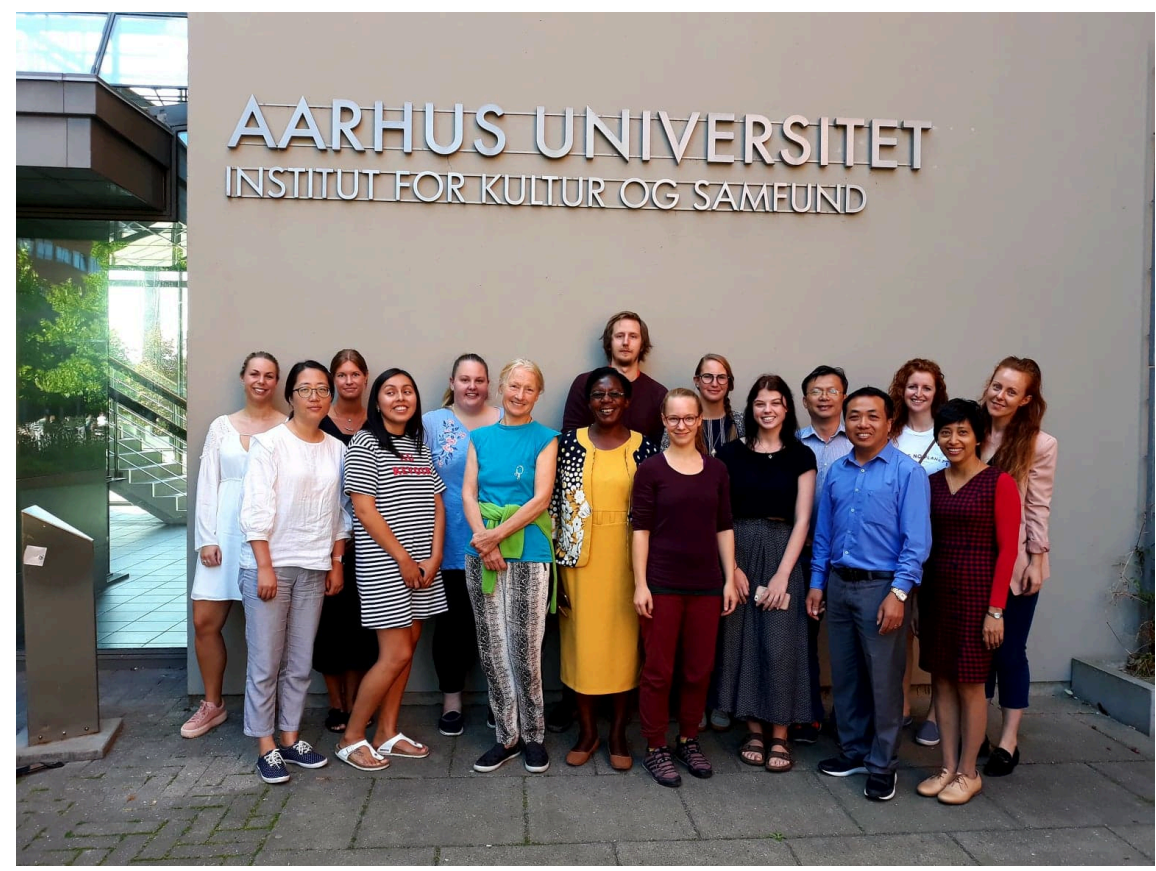

Photo - Courtesy of Sacha Lucassen

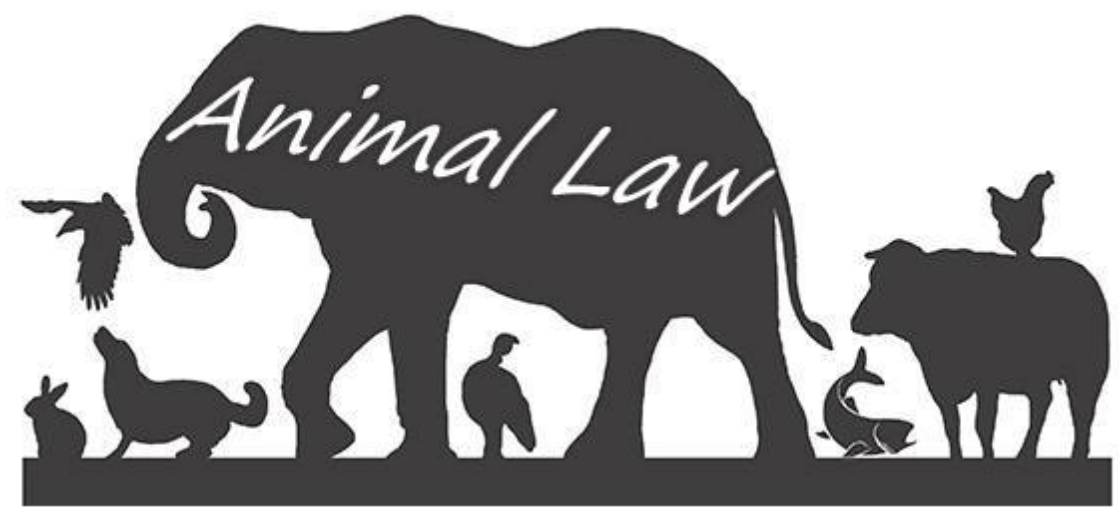

Flyer - Courtesy of Sacha Lucassen 


\section{Program Outline}

\begin{tabular}{|c|c|c|}
\hline Date & Subject & Teacher \\
\hline \multicolumn{3}{|l|}{ Week 1} \\
\hline Cluster 1 & $\begin{array}{l}\text { Animal regulation in the EU and the } \\
\text { Council of Europe }\end{array}$ & \\
\hline Tuesday 3rd July & $\begin{array}{l}\text { Welcome, course outline, course objectives } \\
\text { and expectations }\end{array}$ & Sacha Lucassen \\
\hline Wednesday $4^{\text {th }}$ July & $\begin{array}{l}\text { The EU's political institutions and EU law- } \\
\text { making in the ordinary legislative procedure }\end{array}$ & Klaas Maes \\
\hline Thursday $5^{\text {th }}$ July & $\begin{array}{l}\text { The EU's legal structure and court system + } \\
\text { representing the interests }\end{array}$ & Klaas Maes \\
\hline Friday $6^{\text {th }}$ July & $\begin{array}{l}\text { Animal protection in a historical perspective } \\
\text { and in current EU legislation (Art. } 13 \text { TFEU) }\end{array}$ & Sacha Lucassen \\
\hline \multicolumn{3}{|l|}{ Week 2} \\
\hline Cluster 2 & Animal Protection and the WTO & \\
\hline Monday 9th July & $\begin{array}{l}\text { Trade liberalization and European Union } \\
\text { animal welfare protecting trade measures }\end{array}$ & Iyan Offor \\
\hline Tuesday 10th July & $\begin{array}{l}\text { The World Trade Organization's chilling effect } \\
\text { on EU animal welfare legislation }\end{array}$ & Iyan Offor \\
\hline Cluster 3 & The regulation on animals & \\
\hline Wednesday 11th July & $\begin{array}{l}\text { The interplay between science and animal } \\
\text { welfare legislation - the concepts of sentience } \\
\text { and animal based measures }\end{array}$ & Sacha Lucassen \\
\hline Thursday 12th July & $\begin{array}{l}\text { European Law on animals as it stands and } \\
\text { bottlenecks for its implementation }\end{array}$ & Sacha Lucassen \\
\hline Friday 13th July & $\begin{array}{l}\text { The legal protection of animals in a European } \\
\text { and global perspective }\end{array}$ & Sacha Lucassen \\
\hline \multicolumn{3}{|l|}{ Week 3} \\
\hline Cluster 4 & $\begin{array}{l}\text { The different approaches to the } \\
\text { regulation of animals }\end{array}$ & \\
\hline Monday 16th July & $\begin{array}{l}\text { Philosophical overview on moral anthropo- } \\
\text { centrism in relation to animal interests. }\end{array}$ & Alessia Bacigalupo \\
\hline Tuesday 17 th July & $\begin{array}{l}\text { Contemporary standpoints on the moral status } \\
\text { of non-human animals. }\end{array}$ & Alessia Bacigalupo \\
\hline Wednesday 18th July & $\begin{array}{l}\text { Considering the link between non-human } \\
\text { animal abuse and human violence }\end{array}$ & Tarah Daly \\
\hline Thursday 19th July & Legal rights for non-human animals & Sacha Lucassen \\
\hline \multicolumn{3}{|l|}{ Exam session } \\
\hline Friday 20th July & Exam session & Sacha Lucassen \\
\hline
\end{tabular}

Program - Courtesy of Sacha Lucassen 